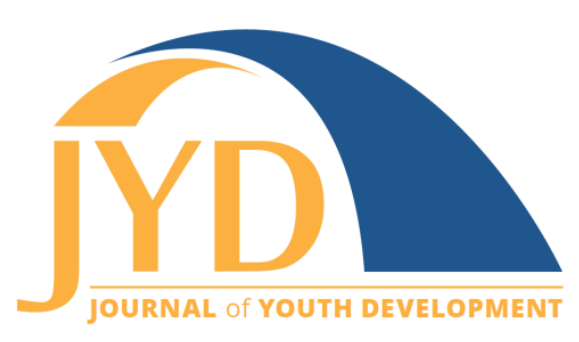

http://jyd.pitt.edu/ | Vol. 16 Issue 1 DOI 10.5195/jyd.2021.906 | ISSN 2325-4017 (online)

\title{
Using the 4-H Essential Elements to Evaluate Teen Programming
}

Joy R. Lile

Washington State Department of Children, Youth and Families

joy.lile@dcyf.wa.gov

Elizabeth H. Weybright

Washington State University

elizabeth.weybright@wsu.edu

\section{Pam Watson}

Washington State University

pwatson@wsu.edu

\begin{abstract}
National and state trends indicate participation in 4-H programming declines throughout adolescence. Past research suggests factors that may influence recruitment and retention of teens into youth development programming. Washington State University undertook an evaluation to understand the needs and desires of teens in the 4-H program and make recommendations for improvements to recruitment and retention of teens in 4-H. The study sample was made up of 93 young people aged 12 to 19 years who participated in the online survey. Results included youth demographics, participation styles, communication preferences, youth outcomes, and feedback about program benefits and opportunities for growth. The results of this study are reviewed and framed within the 4-H Essential Elements.

Recommendations are made to leverage youth voice and encourage innovation in 4-H teen programming.
\end{abstract}

Key words: adolescence, 4-H, program evaluation, needs assessment, Essential Elements

\section{Introduction}

4-H is the largest youth organization in the United States (Downey et al., 2014) serving an estimated 6 million young people annually (National 4-H Council, 2019). Programming is grounded in the 4-H Essential Elements of belonging, mastery, independence, and generosity, which are deemed important programmatic factors necessary for promoting positive youth

(cc) EY New articles in this journal are licensed under a Creative Commons Attribution 4.0 License. This journal is published by the University Library System, University of Pittsburgh and is cosponsored by the University of Pittsburgh Press. The Journal of Youth Development is the official peer-reviewed publication of the National Association of Extension 4-H Youth Development Professionals and the National AfterSchool Association. 


\section{Evaluating Teen Programs Using Essential Elements}

development (Kress, 2005). In turn, the Essential Elements serve as program quality standards and promote factors such as youth engagement, which are important for high-quality youth development programs (Arnold, 2018). Positive youth development frameworks, such as the Essential Elements, not only inform programming, but can also be used for program evaluation purposes. Ongoing program evaluation is necessary, but often limited, in positive youth development programs (Interagency Working Group on Youth Programs, 2016). National 4-H Council developed the 4-H Common Measures to standardize indicators of program quality and outcomes across 4-H programs (Lewis et al., 2015). In addition, programs must provide developmentally appropriate, valuable, and motivating experiences for youth. Guided by the 4-H Essential Elements and Common Measures, Washington State University (WSU) 4-H conducted a summative evaluation of older 4-H youth ages 12 to 19 years (referred to as "youth" within the current study). We sought to understand what outcomes youth exhibit, what program components motivated youth to remain in $4-\mathrm{H}$, and what they would like to see more of in 4-H.

\section{Literature Review}

Youth development programs are defined as "developmentally appropriate programs designed to prepare adolescents for productive adulthood by providing opportunities and supports to help them gain the competencies and knowledge needed to meet the increasing challenges they will face as they mature" (Roth et al., 1998, p.427). These programs play an important role as a developmental context outside of school, home, and work. However, the benefits of youth development programs are achieved only for those who directly participate. Greater engagement in youth development programs is associated with positive outcomes such as academic engagement (e.g., Shernoff, 2010). However, maintaining youth engagement longterm is a challenge.

\section{Declining Participation}

Attrition in youth development programs, including $4-\mathrm{H}$, is a well-documented phenomenon (Anderson-Butcher et al., 2003; Harder et al., 2005; Weisman \& Gottfredson, 2001). Nationally, a drop-off in 4-H participation generally occurs after 11 years of age (Newby \& Sallee, 2011), which coincides with the transition to middle school for many young people. This pattern is evident in WSU 4-H, where enrollment increases, peaking in fifth grade, and then precipitously declines. 


\section{Evaluating Teen Programs Using Essential Elements}

Dropout has been attributed to factors that "push" young people out of clubs, as well as those that "pull" youth to other opportunities outside of 4-H. Push factors include poor relationships with adults, negative experiences with competition (Albright \& Ferrari, 2010), lack of stimulating challenges in clubs, perceived stigma of 4- $\mathrm{H}$ being for younger youth, lack of parental and youth understanding of program requirements (Weisman \& Gottfredson, 2001), scheduling conflicts, lack of parental/sibling involvement, and lack of alignment with personal values and goals (Defore et al., 2011). Pull factors that draw youth out of 4- $\mathrm{H}$ include interest in more advanced subject matter (Newby \& Sallee, 2011) and participation in other family (e.g., babysitting siblings) and non-family (e.g., sports, jobs) activities (Okeke, 2008). Among these push and pull factors for leaving 4-H are examples of programs not meeting youths' developmental needs (e.g., lack of challenge, interest in more advanced subject matter.)

\section{Meeting Developmental Needs}

Developmentally, youth approximately 12 through 18 years old are at a stage where identity, autonomy, voice, and belonging are of high importance. Retention of youth in the 4-H program has been attributed to the availability of developmentally appropriate opportunities including youth-adult partnerships and leadership opportunities (Weybright et al., 2016), focusing on building skills to promote personal goals (McGuire et al., 2016), and promoting belonging/inclusiveness (Newby \& Sallee, 2011). Including opportunities for belonging can mean respecting and celebrating youths' identities, including diverse races, ethnicities, and LGBTQ+ status. Incorporating youth voice into the design, implementation, and evaluation of youth development programs creates positive developmental experiences for young people and helps ensure programs are responsive to participant needs (Akiva et al., 2014; Powers \& Tiffany, 2006). State programs that are responsive to developmental needs and support youths' autonomy will seek input from youth in program-related decision-making, planning, implementation, and evaluation.

\section{The Role of 4-H Essential Elements}

Recruiting and retaining youth rely on providing high-quality, developmentally appropriate, challenging, and fun activities. Anderson-Butcher (2005) identified factors important to initiating and maintaining teen involvement in youth development programs including opportunities, interest and relevance, competence, autonomy, and relatedness. She described how programs should provide opportunities to youth that are of interest and relevant to their desires and match their motivation. Key motivators include competence, or experiences that promote ability, effort, and learning; autonomy, or promoting personal responsibility for one's actions 


\section{Evaluating Teen Programs Using Essential Elements}

and solving problems independently; and relatedness, or having strong social connections with others, including peers and caring adults. These same factors align with the 4-H Essential Elements (in italics) where belonging aligns with Anderson-Butcher's relatedness, mastery with competence, independence with autonomy, and finally generosity with interest in helping others. When programs have these indicators of quality, they are more likely to produce positive outcomes, and vice-versa. Programs with low efficacy may lack key program ingredients (Anderson-Butcher) associated with greater program engagement. Given the connections between developmentally appropriate programming driven by the 4-H Essential Elements and youth program engagement, it is clear that developmentally challenging and relationally supportive programs are necessary to retain youth participation and support positive development.

\section{Study Purpose}

The current study evaluated WSU 4-H programs using quantitative and qualitative survey data. Measures of program quality and program outcomes were included with the rationale that highquality programs produce positive development outcomes (Roth \& Brooks-Gunn, 2016). Survey data from youth involved in state 4-H programming was collected to explore what program outcomes youth experienced in $4-\mathrm{H}$ and gather feedback on what was and was not working well from youths' perspectives.

\section{Methods}

\section{Participants}

Our sample was drawn from youth aged 12-19 years old enrolled in WSU 4-H programs for the 2017-2018 year, which included 8,550 youth enrolled in community clubs statewide. A total of 105 teens completed the survey. A screening question eliminated those younger than 12 or older than 19 years old $(n=12)$, leaving a study sample of 93 youths of whom $78 \%(n=73)$ completed the survey in its entirety (i.e., answered all questions). The highest responses came from youth 14 to 16 years old. Data were collected from October 2017 to February 2018. Youth were recruited via direct and snowball sampling through 4-H county and state newsletters, online communications, and in-person at events and programs including two regional Teen Rallies and the statewide Know Your Government (KYG) program.

To allow for youth voice in the evaluation process, researchers sought input from state ambassadors (SAs), statewide leaders who organize leadership activities for other youth across 


\section{Evaluating Teen Programs Using Essential Elements}

the state. The SA group was engaged throughout the study in recruitment, study design, and providing validation and context for results (i.e., member checking; Torrance, 2012). At each of these stages, roughly 12 to 15 SAs participated, though membership of the SA group changed during the study.

The study was reviewed and approved by WSU Institutional Review Board. The survey was created in Qualtrics and distributed via an HTTP link and QR code. Youth who completed the survey were entered in a drawing for a \$25 Amazon gift card. Gift card drawings occurred monthly and four youth received gift cards.

\section{Measures}

The survey instrument was developed by WSU Extension- and department-based faculty with input from SAs and consisted of demographic questions and select items adapted from 4-H Common Measures 1.0 (Lewis et al., 2015). SAs tested and provided feedback to improve readability and clarity of survey questions.

\section{Demographics}

Demographic items included gender (male, female, other) and race/ethnicity (Black or African American, Asian, American Indian or Pacific Islander, White [non-Hispanic], Hispanic, Other). 4- $\mathrm{H}$ items included county of 4- $\mathrm{H}$ enrollment, years in $4-\mathrm{H}$, and age when starting 4- $\mathrm{H}$.

\section{Youth Outcomes}

Youth outcomes items were modeled after the Common Measures 1.0 (previously called Common Measures) and used as a means of outcome evaluation. Common Measures 2.0 items were released the same year (2017) as the start of data collection and were not yet validated (Mullendore, n.d.). Rather than using the full Common Measures 1.0 scales, we selected key sub-scale questions to capture a broad range of experiences while reducing survey fatigue and attrition. SA feedback suggested reducing the number of items on the survey and prior use of the full Common Measures scales reported large amounts of missing data (e.g., Lewis et al., 2015).

Nine items were from Youth Development sub-scales with response options of Yes, Sometimes, and No. Items came from sub-scales of Positive Choices, Communication, Connection, and Contribution and reflect the 4-H Essential Elements as discussed in 4-H documents (Kress, 2004; Martz et al., 2009; National 4-H Council, 2011). Items from the sub-scale of Positive Choices included, "I can explain why my decision is a good one and I have a plan for reaching 


\section{Evaluating Teen Programs Using Essential Elements}

my goals" (Mastery). Items from the Communication sub-scale included, "I have the confidence to speak in front of groups" (Mastery), "I know who I can go to if I need help with a problem" (Belonging), and "I can stand up for things that are important to me" (Independence). Items from the Connection sub-scale were, "I work well with other youth and I can work successfully with adults" (Belonging). Items from the Contribution sub-scale were, "I like to work with others to solve problems" (Independence) and "I led a project that made a difference in my community" (Generosity).

Five items were used to capture key state-wide, program-targeted outcomes related to citizenship and college/career readiness. Response options were Yes, No, and I'm not sure. Items included, "I have learned about Washington state government," "I gained skills that will help me in the future," "I have learned job preparation skills (for example resume writing, interviewing, cashiering, etc.)," "I have learned skills to help me live independently (for example budgeting, cooking, staying healthy, record keeping, etc.)," and "I have learned about how my interests align with career/college/technical school choices."

\section{Experiences in 4-H}

The survey also included three open-ended questions on youth experiences in 4- $\mathrm{H}$ as a means of summative evaluation. These questions included (a) What is a positive experience you've had in 4-H?, (b) What is something you would change about 4-H?, and (c) What is something you wish you could do more of in $4-\mathrm{H}$ ?

\section{Data Analysis}

Prevalences and patterns within quantitative data were identified using descriptive statistics (means, proportions). Qualitative data were analyzed using the constant comparative method of open, axial, and selective coding (Merriam \& Tisdale, 2016). In addition to identifying emergent codes, a priori codes were used based on the 4-H Essential Elements of belonging, mastery, independence, and generosity (Martz et al., 2009). All research team members agreed on a priori codes prior to coding. One member coded transcripts and developed a codebook in regular consultation with two additional members until all members reached $100 \%$ agreement on codes and broader emergent themes (i.e., next level categories of codes.) Codes and themes were presented to SAs as a form of member checking to ensure trustworthiness. In a discussion about the findings, the SAs generally agreed with the results and provided additional insights on ways to encourage teen leadership (including being more appreciative of teen contributions), project ideas for teens (including arts, life-skills, and career readiness skills), and better engagement of adults through teen advisor training for adult volunteers. The SAs also 


\section{Evaluating Teen Programs Using Essential Elements}

expressed appreciation that they were included in the process and a desire for more interaction with state leadership about the direction of the state program.

\section{Results}

\section{Demographics}

Youth were 15 years old on average $(S D=1.9)$, primarily female $(80 \%)$ and White $(77.4 \%)$ with 5.4\% Hispanic, 4.3\% Asian, 4.3\% African American, 3.2\% American Indian/Alaskan Native and $5.4 \%$ Other. Compared to the state enrollment data, fewer males (46\% statewide), greater numbers of White youth (73\% statewide), and more non-Hispanic youth (76\% statewide) participated. The average age at which participants had joined $4-\mathrm{H}$ was 9 years and $75 \%$ had been enrolled for 4 or more years at the time of the study.

\section{Youth Outcomes}

\section{Youth Development}

Youth development outcomes (see Table 1) demonstrated more than $90 \%$ of youth reported experiencing outcomes related to belonging, mastery, and independence. Those reporting outcomes related to generosity were lower at $77 \%$, but this still captured the majority of youth.

Table 1. Youth Outcome Responses and Means

\begin{tabular}{|c|c|c|c|c|c|}
\hline \multirow{2}{*}{$\begin{array}{l}\text { 4-H } \\
\text { Essential } \\
\text { Element }\end{array}$} & \multirow[t]{2}{*}{ Outcome } & \multicolumn{3}{|c|}{ Response percentage } & \multirow[t]{2}{*}{ Mean (SD) } \\
\hline & & Yes & $\begin{array}{l}\text { Some- } \\
\text { times }\end{array}$ & No & \\
\hline \multirow{3}{*}{ Belonging } & $\begin{array}{l}\text { I know who I can go to if I need help with a } \\
\text { problem. }\end{array}$ & $74.1 \%$ & $18.8 \%$ & $7.1 \%$ & $1.33(0.60)$ \\
\hline & I work well with other youth. & $78.8 \%$ & $20.0 \%$ & $1.2 \%$ & $1.22(0.44)$ \\
\hline & I can work successfully with adults. & $87.1 \%$ & $8.2 \%$ & $4.7 \%$ & $1.18(0.49)$ \\
\hline \multirow{3}{*}{ Mastery } & I can explain why my decision is a good one. & $75.3 \%$ & $20.0 \%$ & $4.7 \%$ & $1.29(0.55)$ \\
\hline & I have a plan for reaching my goals. & $76.5 \%$ & $20.0 \%$ & $3.5 \%$ & $1.27(0.52)$ \\
\hline & I have the confidence to speak in front of groups. & $63.5 \%$ & $31.8 \%$ & $4.7 \%$ & $1.41(0.58)$ \\
\hline \multirow{2}{*}{$\begin{array}{l}\text { Indepen- } \\
\text { dence }\end{array}$} & I can stand up for things that are important to me. & $81.2 \%$ & $14.1 \%$ & $4.7 \%$ & $1.24(0.52)$ \\
\hline & I like to work with others to solve problems. & $62.4 \%$ & $29.4 \%$ & $8.2 \%$ & $1.46(0.64)$ \\
\hline Generosity & $\begin{array}{l}\text { I led a project that made a difference in my } \\
\text { community. }\end{array}$ & $37.7 \%$ & $38.8 \%$ & $23.5 \%$ & $1.86(0.77)$ \\
\hline
\end{tabular}

Note. $n=85$; Response options ranged from 1 (Yes) to 3 (No). 


\section{Citizenship and Career/College Readiness}

Items related to citizenship and career/college readiness demonstrated mixed findings. Most youth reported learning about skills for the future and living independently as well as alignment of interests with post-high-school choices, but fewer youth reported gaining job preparation skills and only $23 \%$ of youth learned about state government.

Table 2: Citizenship and Career/College Readiness Outcome Responses

\begin{tabular}{|l|c|c|c|}
\hline \multirow{2}{*}{ Outcome } & \multicolumn{2}{|c|}{ Response percentage } \\
\cline { 2 - 4 } & Yes & No & I'm not sure. \\
\hline I gained skills that will help me in the future. & $94.1 \%$ & $2.4 \%$ & $3.6 \%$ \\
\hline $\begin{array}{l}\text { I have learned some skills to help me live independently (for } \\
\text { example budgeting, cooking, staying healthy, record keeping, etc.). }\end{array}$ & $80.0 \%$ & $14.1 \%$ & $5.9 \%$ \\
\hline $\begin{array}{l}\text { I have learned about how my interests align with } \\
\text { career/college/technical school choices. }\end{array}$ & $72.9 \%$ & $11.8 \%$ & $15.3 \%$ \\
\hline $\begin{array}{l}\text { I have learned some job preparation skills (for example resume } \\
\text { writing, interviewing, cashiering, etc.) }\end{array}$ & $62.4 \%$ & $28.2 \%$ & $9.4 \%$ \\
\hline I have learned about Washington state government. & $23.5 \%$ & $63.5 \%$ & $12.9 \%$ \\
\hline
\end{tabular}

Note. $n=85$.

\section{Qualitative Outcomes}

\section{Positive Experiences in 4-H}

Positive experiences that teens reported aligned thematically with the Essential Elements of 4-H (Kress, 2005). Teens ( $n=75$ answered this question) mentioned development of mastery (45\%), belonging (41\%), independence (20\%), and generosity (17\%), as well as reporting enjoyment of special events (5\%) and general enjoyment of the program (3\%). Themes related to the 4-H Essential Elements are described below, along with quotes and age and gender of youth respondent.

Mastery (45\%). Benefits to mastery for youth include competing at fairs and shows at the state, county, and national levels; learning new life skills like cooking, sewing, public speaking, record keeping, and leadership; and learning about raising and showing their project animals. One youth (female, 16) stated "every event has inspired me to do something new, even if I have done it before." 


\section{Evaluating Teen Programs Using Essential Elements}

Belonging (41\%). Youth most often spoke about making and sustaining friendships through the 4-H project. One youth (female, 18) benefited from "being able to make connections with people that I would have never met otherwise." Four youth were generally positive about the program, while three shard they had developed connections with adults such as "learning how to communicate with judges," (female, 16). Three other youth stated they learned about teamwork and two said they felt supported in $4-\mathrm{H}$.

Independence (20\%). Youth who described independence mostly spoke of gaining confidence in public speaking. For example, one youth (female, 18) mentioned "giving presentations and demonstrations have helped my independence and leadership skills." Six youth spoke about experiencing leadership in their clubs or on county advisory boards and two spoke about a sense of accomplishment from $4-\mathrm{H}$.

Generosity (17\%). Eight youth spoke about their enjoyment of teaching and mentoring younger youth in 4-H. One youth (female, 17) stated "As the president of my 4-H club the most positive experience I've had was seeing younger kids understand concepts that I was teaching them. It really gives the confidence that I can help people." An additional five youth spoke about the benefits of service to their clubs and communities, including carrying flags, doing outreach with the community about 4- $\mathrm{H}$, or doing service projects to benefit others.

The following quotes provide additional, overlapping exemplars for 4-H Essential Elements themes:

Belonging and mastery. Having fun with friends at the county fair, state-wide rabbit shows, and national rabbit shows. 4-H has given me the opportunity to meet other people with similar interests and hobbies (in this case rabbit raising), and has helped me make new friends and learn new abilities. (Gender not identified, 17)

Belonging and generosity. When I was 10, I was going to [local county] 4-H camp, where I currently work once a year. I was having a really tough week, and none of my activities were any fun for me. I was moping about, feeling sorry for myself, and then a counselor named Pat [pseudonym] came up to me and asked what was up. When he heard what I had to say, he smiled and said, "Cheer up kid, I'll hang out with you. "That was probably the highlight of that camp, and I constantly strive to be more like Pat while I'm at camp as a counselor or when I'm working with other youth. That was a really good experience. (Male, 17) 


\section{Evaluating Teen Programs Using Essential Elements}

Mastery and independence. I have learned responsibility, leadership, public presenting and social skills that will positively benefit me in my future. Some examples of this are the yearly Public Presentations and interacting with the public at [state fairs]. (Female, 14)

\section{What Would Teens Change?}

When asked what they would change about 4-H $(n=68)$, teens most often gave specific examples of policies and procedures (29\%) at the club, county, and state level that made $4-\mathrm{H}$ challenging for them. Examples included the ways in which club leadership was determined, requirements for record books/presentations/dress code in the county, and statewide policies on age, fees, and religion. Many of these issues related to youth feeling like the 4-H atmosphere was overly restrictive. For example, one youth (female, 17) said "We were very limited to what fundraiser we could do, which led to less involvement and public speaking opportunities."

Other themes including communication (18\%), teen activities (12\%), and marketing or publicity $(10 \%)$ revolved around spreading knowledge about existing opportunities and/or designing new opportunities for teens in 4-H. One teen (female, 18) voiced this desire for engagement saying, "I wish that we had more chances to interact with the community and explain the benefits of 4-H."

Teens wanted more communication at the state level about teen events, more teen events scheduled, and more promotion of $4-\mathrm{H}$ in general. Marketing and communication often overlapped, such as when one teen (female, 15) said, "I think better communication, and to get the 4-H brand out there more, especially for events."

Five youths (7\%) said that they craved more youth input in their clubs and programs. For example, one youth (female, 17) stated, "I would change the views or feelings around 4-H or in 4-H, I feel as though sometimes us older kids who are seniors in 4- $\mathrm{H}$ are not listened to or our ideas are not taken into consideration."

Sixteen teens (24\%) answered with "nothing" or "I don't know" when asked what they would change about $4-\mathrm{H}$. 


\section{Evaluating Teen Programs Using Essential Elements}

\section{What Would Teens Like More Of?}

When asked about something they wish they could do more of in 4-H, teens' $(n=73)$ most common answer related to opportunities to show with their project or animal (22\%). For example, one youth (female, 16) said, "I wish I could be a part of more than one state team at once. It opens ALOT [sic] more doors for kids if they don't have to put it off and try to make the team again next year."

Other themes included

- Social/fun events (21\%). Youth expressed a desire for more events at the local and state levels, as well as social activities at fairs where they could interact with people from other projects and other counties. "I wish there was a way I could collaborate with other 4-Hers more. At the Fair, each group is very clique like" (female, 14).

- Teen leadership opportunities (19\%). These participants spoke specifically about desiring more leadership opportunities for themselves and their peers, and explicitly wanting to help younger youths or have a voice in the 4-H program. "I would like to have the older members spread out and make friends and interact with the younger, new members" (female, 14).

- Learning (16\%). Responses related to learning were split evenly between youths who wanted to learn more about a specific project and those who desired more "life skill" learning, including cooking, civic engagement, resume building, hands-on learning, etc. in their clubs. "I wish that my club would focus more on life skills instead of just our projects" (male, 13). Two youths mentioned a desire to learn more about STEM or robotics.

- Community service (8\%). These youth desired to do more service as part of 4-H including specific service activities like working at a homeless shelter or general ideas like volunteering, community projects, or sharing about the benefits of 4-H. "County participation. As well as community service participation. People talk about how they want to help but they never do. People need to be held accountable so that not the same people are doing everything all the time. It burns people out fast" (female, 18).

\section{Discussion}

The experiences of young participants are an important part of the WSU 4-H model. Engagement in youth development programs is associated with positive outcomes and maintaining participation (Anderson-Butcher, 2005). Statewide evaluation results found youth expressed the desire for more developmentally appropriate challenges and opportunities to take 


\section{Evaluating Teen Programs Using Essential Elements}

on more responsibility, both within their clubs and in special events statewide. Youth also desired opportunities to expand their social circles and learn about potential career and college pathways. Using data from the current study, we have identified a number of implications and next steps. Given the focus on the 4-H Essential Elements as a guiding framework for 4-H (Martz et al. , 2009) and the current study, the themes of belonging, mastery, independence and generosity are continued into the discussion and implications.

\section{Belonging}

The social context plays a key role in adolescent development. One contributing factor that helps youth maintain participation in out-of-school programs is how well they feel they fit in and how welcome they feel. This is evident from qualitative themes from this data, which point to the development of friendships in 4- $\mathrm{H}$, and the support friendships and caring adults provide. However, belonging is also an individual experience, and current 4- $\mathrm{H}$ practices may feel welcoming to some but not others. When asked what they would change about 4- $\mathrm{H}$, a number of youths commented that club elections sometimes feel predetermined. This is a sign these young people feel a lack of welcoming and belonging in the club environment.

In particular, prior research finds different experiences for male and female adolescents. This aligns with, and could explain, the skewed gender demographics of the study sample. The National 4-H Enrollment Report (USDA Research, Education \& Economics Information System, 2014) indicates males are in the minority, but only slightly (47.9\%); our sample was therefore not nationally representative of $4-\mathrm{H}$ gender demographics. Adolescent females report more satisfying 4-H experiences than males (Bartoszuk \& Randall, 2011; Homan et al., 2007). However, this may also be due to factors outside of 4-H. For example, parents and friends tend to encourage girls to be more active in $4-\mathrm{H}$ than boys and females report a higher likelihood their friends would stay in 4-H.

In addition to gender, another demographic factor is race/ethnicity. Historically, 4-H has predominantly reached White youth (e.g., Lerner \& Lerner, 2013). The need to focus on diversity and inclusion is acknowledged within the recent 4-H Social Justice Youth Development publication (Fields et al., 2018). In particular, this document provides theoretical background and self-reflection questions for not only adults, but also youths themselves. This publication, paired with other tools, such as the Youth Program Quality Assessment (High/Scope Educational Research Foundation, 2005) to measure belonging, provides guidelines and a way forward to assess and prioritize factors important to promote belonging. 


\section{Evaluating Teen Programs Using Essential Elements}

\section{Mastery}

In current (K-12) instruction, problem-solving skills are presented in an abstract form removed from their application to knowledge, which can make transfer to real-world situations difficult (Bellanca, 2010). Bellanca points out the opportunities for life skills development are in decline through public school systems. With this trend, it is important to note 4-H youth in this sample overwhelmingly reported gaining life skills: $94 \%$ of youth surveyed expressed that they had gained skills that will help them in the future.

One opportunity for 4- $\mathrm{H}$ youth to demonstrate mastery is through a teens-as-teachers approach with the Youth Advocates for Health program (YA4-H!; Arnold et al., 2015). This program allows youth to learn about healthy eating and nutrition habits in a train-the-trainer atmosphere and then take the program into local elementary schools, teaching and mentoring younger children (Weybright et. al, 2018). Other avenues for mastery in 4-H are through public presentations, record books, and exhibiting at county fairs. However, it is sometimes hard to relate to the public exactly what skills have been mastered by the youth through these projects.

In 4-H we build relationships with caring adults to guide youth towards positive developmental trajectories. Building problem-solving skills in the 4-H program can help youth reach this goal. Most youth respondents in this survey (73\%) learned how their interests aligned with career or educational choices and $62 \%$ gained job preparation skills. This points to positive developmental trajectories in which youth can feel confident about their future. Only a quarter of the young people in the current study reported learning about state government. Despite KYG being one of Washington's major 4-H events, only a few hundred youths each year participate which may explain this response. Increasing engagement in KYG should be an emphasis moving forward.

\section{Independence}

While youth in this study reported they experienced opportunities for independence in their clubs, they also expressed a desire for more leadership roles and open communication. The majority of young people reported gaining skills related to independent living. In our qualitative data, $20 \%$ of the teens reported indicators of independence skills that "will positively benefit me in my future." 


\section{Evaluating Teen Programs Using Essential Elements}

However, there was a clear desire for more youth independence and voice. Some youths reported they wanted more youth input in their clubs and programs and others reported a desire for more leadership opportunities at the local and state levels. Several youths reported issues with the policies and procedures at county and state levels, a sign they do not feel like their voice is represented in policy decisions. The SAs confirmed these concerns, stating they felt some club volunteers were heavy-handed and limited youths' ability to lead. Honoring youth voice is an essential component to retention and recruitment (McGuire et al., 2016) and additional adult volunteer training on how to effectively work with youth is likely needed.

\section{Generosity}

Youth in the study expressed ambivalence about their opportunities for generosity in the state 4-H programs. In qualitative data, teens expressed enjoyment in mentoring and teaching younger youth. However, in quantitative data, about a third of youth said they led a project that made a difference in their community. SAs shared that more acknowledgement or appreciation from adults for youth contributions might help them to be surer of their impact. Youth often said they would like more opportunities to interact with their communities and "explain the benefits of $4-\mathrm{H} . "$

Research suggests teen teaching and other programs where teens mentor younger youth can help develop relational skills, caring, and reciprocity (Arnold et al., 2016; Worker et al., 2018) as well as increasing mastery and internalization of the concepts taught (Weybright et al., 2018). Community engagement is a developmentally important support for youth (Sherrod et al., 2002) and community service programs can help build social and emotional skills (Chung and McBride, 2015). 4-H youth programs should support development of generosity through community engagement and service learning opportunities, such as teen teaching programs.

\section{Recommendations for Policy and Practice}

A number of recommendations were developed based on results. This study was conducted as an evaluation for the WSU Teen Program. Based upon prior literature and current study findings, recommendations to enhance $4-\mathrm{H}$ youth programs include

\section{- Strengthen adolescent-specific programming opportunities in the state.} Opportunities both within and beyond the traditional community club model that is most prevalent in WSU 4-H should be expanded. This may include, for example: training adult volunteers with developmentally-appropriate material to facilitate youth groups; 


\section{Evaluating Teen Programs Using Essential Elements}

providing more opportunities for youth from different counties to interact at state-level fairs, shows, and teen programs; providing more life-skills and career-focused educational opportunities; and ensuring opportunities for engaging in community service. This may also include developing and/or expanding a network of county teen groups who can work on these activities at the county level, to feed into state-level leadership opportunities.

- Work to continually improve and support youth voice and input into all levels of 4-H programming through leadership, engagement, and evaluation. SAs expressed appreciation for being included in this survey, and youth voice should be included in all evaluation projects. Training adults and providing a model or framework for adolescent leadership and voice at every level of 4-H programming in the state (club, county, district, and state) is invaluable in ensuring that youth voice is prioritized.

- Continue to assess policy and programming around inclusion (e.g., Fields et al., 2018). While these findings have limited relevance for diverse audiences, it is clear that engagement and evaluation programs need to do a better job at including diverse voices, and that WSU 4-H programs need to better-engage youth from diverse backgrounds. One strategy could be to partner with diverse groups to improve belonging, inclusion, and equity in $4-\mathrm{H}$ youth programs.

\section{Summary}

The data from the WSU 4-H Teen evaluation confirms the aspects of programming which young people find most enjoyable are also developmentally appropriate opportunities for them. These include opportunities to learn new skills, form new positive relationships, and give back by teaching and serving others. Youth know, intrinsically, what kinds of opportunities will help them to be successful. A program that can provide these opportunities, while also marketing them successfully to teens and providing ample opportunities for voice and input, will be successful in recruiting and retaining youth participants.

\section{Limitations}

Some issues limit the generalizability of our results. Due to the convenience sample used and lack of a control group, findings may not be generalizable to other states, to those within WSU 4-H who did not respond or who left the program, and we cannot confirm causal relationships between participation in 4- $\mathrm{H}$ and outcomes reported. Generalizability of findings is also limited to youth who were already in the program. Responses were generally from White, female youth 


\section{Evaluating Teen Programs Using Essential Elements}

so male and non-White youth are not well represented. Despite this, results generally align with prior research, suggesting implications may apply to $4-\mathrm{H}$ and youth development programming.

\section{Conclusion}

The current survey provided an opportunity to gather youth voice statewide using both common measures survey items and open-ended questions. Youth reported positive developmental outcomes from the 4-H program but also gave feedback on how to make improvements. Recommendations for how to better communicate with teens, incorporate youth voice, and market teen events have been shared at the state level, and results can support other states to enrich their $4-\mathrm{H}$ teen programming.

\section{References}

Akiva, T., Cortina, K., \& Smith, C. (2014). Involving youth in program decision-making: How common and what might it do for youth? Journal of Youth \& Adolescence, 43(11), 1844-1860.

\section{https://doi.org/10.1007/s10964-014-0183-y}

Albright, M. B., \& Ferrari, T. M. (2010). "Push" and "pull" A qualitative study of factors that contribute to older youth leaving the 4-H program. Journal of Youth Development, 5(3), 55-74. https://doi.org/10.5195/jyd.2010.209

Anderson-Butcher, D. (2005). Recruitment and retention in youth development programming. The Prevention Researcher, 12(2), 3-6.

Anderson-Butcher, D., Newsom, W. S., \& Ferrari, T. M. (2003). Participation in Boys and Girls Clubs and relationship to youth outcomes. Journal of Community Psychology, 31(1), 39-55.

Arnold, M. E. (2018). From context to outcomes: A thriving model of 4-H youth development programs. Journal of Human Sciences and Extension, 6(1), 141-160.

Arnold, M. E., Flesch, J. M., Ashton, C., Black, L., Brody, B., Hosty, M., \& Northway, S. (2016). YA4-H! Youth advocates for health: Impact of a 4-H teens-as-teachers program. Journal of Extension, 54(6), rb5. https://archives.joe.org/joe/2016december/rb5.php

Arnold, M. E., Gifford, L. N., Deen, M. K., Calodich, S., \& Edwards, J. W. (2015). YA4-H! Youth advocates for health - Teens as teachers. Oregon State University Public Health Extension.

Bartoszuk, K., \& Randall, B. A. (2011). Characteristics and perceptions of 4-H participants: Gender and age differences across adolescence. Journal of Extension, 49(3), 48-55.

\section{https://archives.joe.org/joe/2011june/a6.php}

Bellanca, J. A. (Ed.). (2010). 21 st century skills: Rethinking how students learn. Solution Tree Press. 


\section{Evaluating Teen Programs Using Essential Elements}

Chung, S., \& McBride, A. M. (2015). Social and emotional learning in middle school curricula: A service learning model based on positive youth development. Children and Youth Services Review, 53, 192-200. https://doi.org/10.1016/j.childyouth.2015.04.008

Defore, A. B., Fuhrman, N. E., Peake, J. B., \& Duncan, D. W. (2011). Factors influencing 4-H club enrollment and retention in Georgia. Journal of Youth Development, 6(2), 58-71. https://doi.org/10.5195/jyd.2011.188

Downey, L. H., Peterson, D. J., LeMenestrel, S., Leatherman, J., \& Lang, J. (2014). 4-H Healthy Living programs with impact: A national environmental scan. New Directors for Youth Development, 2014(143), 13-24. https://doi.org/10.1002/yd.20101

Fields, N. I., Moncloa, F., \& Smith, C. (2018). 4-H social justice youth development: A guide for youth development professionals. University of Maryland

Harder, A., Lamm, A., Lamm, D., Rask, G., \& Rose, H. (2005). An in-depth look at 4-H enrollment and retention. Journal of Extension, 43(5), rb4. https://archives.joe.org/joe/2005october/rb4.php

High/Scope Educational Research Foundation. (2005). Youth program quality assessment. High/Scope Press.

Homan, G., Dick, J., \& Hedrick, J. (2007). Differences in youth perceptions of Ohio 4-H based on gender. Journal of Extension, 45(5), rb7. https://archives.joe.org/joe/2007october/rb7.php

Interagency Working Group on Youth Programs. (2016). Pathways for youth: Strategic plan for federal collaboration. https://youth.gov/sites/default/files/IWGYP-Pathways for Youth.pdf

Kress, C. (2005). Essential elements of positive youth development. In Strengthening positive youth development environments (pp. 20-23). University of Wisconsin Extension 4-H Program.

Lerner, R. M., \& Lerner, J. V. (2013). The positive development of youth: Report of the findings from the first seven years of the 4-H study of positive youth development. Institute for Applied Research in Youth Development, Tufts University. https://4-h.org/wp-content/uploads/2016/02/4-H-Studyof-Positive-Youth-Development-Full-Report.pdf

Lewis, K. M., Horrillo, S. J., Widaman, K., Worker, S. M., \& Trzesniewski, K. (2015). National 4-H Common Measures: Initial evaluation from California 4-H. Journal of Extension, 53(2), rb3. https://archives.joe.org/joe/2015april/rb3.php

Martz, J., Mincemoyer, C., McNeely, N. N., Bledsoe, L., Dart, P., \& Worthington, K. (2009). Essential elements of 4-H youth development programs. National 4-H Council.

McGuire, J. K., Dworkin, J., Borden, L. M., Perkins, D., \& Russell, S. T. (2016). Youth motivations for program participation. Journal of Youth Development, 11(3), 7-25. https://doi.org/10.5195/jyd.2016.457

Merriam, S. B., \& Tisdell, E. J. (2016). Qualitative research: A guide to design and implementation. (4 ${ }^{\text {th }}$ ed.). Jossey-Bass. 
Journal of Youth Development | http://jyd.pitt.edu/ | Vol. 16 Issue 1 DOI 10.5195/jyd.2021.906

Evaluating Teen Programs Using Essential Elements

Mullendore, J. (n.d.). Getting the most out of Common Measures 2.0. National 4-H Council and University of Nebraska-Lincoln. http://www.4-h.uconn.edu/evaluation/docs/collection/IntroductionCM2.pdf

National 4-H Council. (2019). Annual report 2018. Author. https://4-h.org/wpcontent/uploads/2020/04/National-4-H-Council-FY18B-Annual-Report.pdf

National 4-H Council. (2011). 4-H national headquarters fact sheet: Essential Elements. Author. https://nifa.usda.gov/sites/default/files/resource/Essential\%20Elements\%200f\%204H\%20v.2011.pdf

Newby, L., \& Sallee, J. (2011). 4-H membership recruitment/retention problems: A meta-analysis of possible causes and solutions. Journal of Youth Development, 6(4), 37-46.

\section{https://doi.org/10.5195/jyd.2011.163}

Okeke, L. (2008) Attrition in adolescent after-school programs: Addressing the concern via interviews with program dropouts. Journal of Youth Development, 3(3). https://doi.org/10.5195/iyd.2008.292

Powers, J. L., \& Tiffany, J. S. (2006). Engaging youth in participatory research and evaluation. Journal of Public Health Management and Practice, 12, S79.

Roth, J. L., \& Brooks-Gunn, J. (2016). Evaluating youth development programs: Progress and promise. Applied Developmental Science, 20(3), 188-202. https://doi.org/10.1080/10888691.2015.1113879

Roth, J., Brooks-Gunn, J., Murray, L., \& Foster, W. (1998). Promoting healthy adolescents: Synthesis of youth development program evaluations. Journal of Research on Adolescence, 8(4), 423-459.

Shernoff, D. J. (2010). Engagement in after-school programs as a predictor of social competence and academic performance. American Journal of Community Psychology, 45(3-4), 325-337.

Sherrod, L. R., Flanagan, C., \& Youniss, J. (2002). Dimensions of citizenship and opportunities for youth development: The what, why, when, where, and who of citizenship development. Applied Developmental Science, 6(4), 264-272.

Torrance, H. (2012). Triangulation, respondent validation, and democratic participation in mixed methods research. Journal of Mixed Methods Research, 6(2), 111-123. https://doi.org/10.1177/1558689812437185

USDA Research, Education \& Economics Information System. (2014). National 4-H enrollment report. https://reeis.usda.gov/reports-and-documents/4-h-reports

Weisman, S. A., \& Gottfredson, D. C. (2001). Attrition from after school programs: Characteristics of students who drop out. Prevention Science, 2(3), 201-205. https://doi.org/10.1023/A:1011515024809

Weybright, E. H., Hrncirik, L. M., White, A. J., Cummins, M. M., Deen, M. K., \& Calodich, S. (2016). "I felt really respected and I know she felt respected too": Using youth-adult partnerships to promote 
Journal of Youth Development | http://jyd.pitt.edu/ | Vol. 16 Issue 1 DOI 10.5195/jyd.2021.906

\section{Evaluating Teen Programs Using Essential Elements}

positive youth development in 4-H youth. Journal of Human Sciences and Extension, 4(3), 93110.

Weybright, E. H., Martinez, A. D., Varrella, G., Deen, M. K., \& Wright, K. (2018). Teens as teachers: Positive outcomes and recommendations for promoting healthy nutrition in adolescents. Journal of Youth Development, 13(3), 43-60. https://jyd.pitt.edu/ojs/jyd/article/view/18-13-03-FA-02

Worker, S. M., Iaccopucci, A. M., Bird, M., \& Horowitz, M. (2018). Promoting positive youth development through teenagers-as-teachers programs. Journal of Adolescent Research, 34(1), 30-54. https://doi.org/10.1177/0743558418764089 